\title{
Original
}

\section{Bacterial Contamination Analysis of Residential Toilet Room Environment and Delivery of Residual Bacterial Growth Prevention Efficacy on Residential Toilet Permeable Surfaces Using Toilet Air Freshener Product}

\author{
YOSHIKI ISHIDA ${ }^{1 *}$, RAHUL VYAS ${ }^{1}$, GARIMA CHAUHAN ${ }^{1}$, \\ LILIANA DELGADO ${ }^{1}$, AND HIROKI KOURAI ${ }^{2}$ \\ ${ }^{1}$ Procter and Gamble International Operations SA Singapore branch, 70 Biopolis Street Singapore 138547 \\ ${ }^{2}$ KOURAI Microbiology Laboratory, 230-2, Tomiyoshi Kawauchi-cho, Tokushima 771-0112, Japan
}

Received 14 September, 2020/Accepted 27 January, 2021

\begin{abstract}
Toilet malodor is one of the most concerned malodor in residential houses, so that many technologies and products have been developed by which is aiming to remove or reduce such toilet malodor. Toilet malodour is generated from human faecal matters left inside of toilet bowl and from that deposited outside of toilet bowl such as toilet floors. In order to remove or prevent the malodor generated outside of toilet bowl, it is effective to do more frequent cleaning of toilet room surfaces or place a deodorizer which mask the malodour by perfume. We developed a toilet deodorizer which is preventing malodor generation outside of toilet bowl more effectively by delivering antibacterial efficacy on toilet room permeable surfaces. We analyzed microbiological quality of residential toilet rooms and found that toilet floor is the most contaminated location by bacteria, so that we developed a test method using materials frequently used for residential toilet floors such as vinyl cushion and using bacteria commonly found in toilet room environment. As the results, we found the product can provide bacterial growth prevention efficacy on permeable materials and prevent toilet malodor effectively.
\end{abstract}

Key words : Toilet / Malodor / Toilet air freshener / Bacterial growth prevention.

\section{INTRODUCTION}

Toilet is the place where Japanese consumers are most concerned about malodor. To remove such toilet malodor, consumers are cleaning their toilets frequently; $80 \%$ of consumers clean their toilets once or more in a week. Another compensatory action against such malodor is to place a deodorizer in toilet which usually mask the malodor by perfume technologies. Japanese consumers are very well aware of the need to sanitize toilet space because they know such malodor is produced by bacteria contained in feces and urine. Hence, many toilet cleaning products in market have antibacterial actives that intend to solve their concerns.

Toilet malodor is mainly produced from two sources;

*Corresponding author. Tel: +65-6712-3204, Fax: +65-67121223, E-mail : Ishida.y.1 (a)pg.com primary malodor sources are human wastes and secondary malodor sources are toilet room environment such as toilet bowl, wall and floors. According to the housing and land survey in 2008 by Statistics bureau of Japan, $90.7 \%$ of households in Japan has flush toilet. As such, malodor from human wastes is rather transient and appropriate ventilation of toilet room or air freshener products usage is an effective way to remove malodor from the primary malodor sources. In addition, recent evolution of toilet bowls enable flushing water to remove human wastes more effectively and minimize hard-toreach areas such as underneath of toilet bowl rim by which much less wastes are left. Therefore, malodor from toilet bowl can be solved via frequent cleaning using products that have sanitizing ingredients like quaternary ammonium chloride, sodium hypochlorite. Toilet room walls and floors are also contaminated by human wastes and microorganisms, but these areas are more difficult to 
clean than toilet bowl because these surfaces consist of permeable surfaces such as wall papers, dry walls and vinyl cushions which have rough surfaces. As a result, residual human wastes on these surfaces are decomposed by residual bacteria on the surfaces and produce malodorous molecules that are either released into the air or absorbed in the materials that become secondary malodor sources. The malodor from the secondary malodor sources contribute to the overall malodor and it is often the cause of what consumers perceive as lingering or background malodors. To remove such toilet malodor, toilet air freshener products are often used. However, these products currently in the market usually mask the malodor and they cannot prevent the malodor production from the secondary malodor sources. We have previously developed an air fresher product which release carbonyls and aldehydes that are absorbed in the permeable surface materials and neutralize malodorous chemicals (Vyas et al., 2018).

In this study, we analysed microbiological quality of residential toilet environment to find where in toilet room there is contamination and by how much of bacteria. Based on the information, we developed an in vitro test method to identify an antibacterial technology that can be absorbed in permeable surfaces in toilet room and deliver residual bacteria growth prevention benefit, and develop a toilet deodorizer that can reduce malodor generation from the secondary sources more effectively.

\section{MATERIALS AND METHODS}

\section{Microbiological investigation of Japanese residential toilets}

First study: We selected 10 households in Hyogo prefecture that have at least one boy who can urinate by himself using their toilet (average number of family members is 4.40). Six of them were living in apartments and four of them were living in landed house. In September 2018, the first swab samples were taken from $5 \mathrm{~cm} x$ $15 \mathrm{~cm}$ area listed in Table 1 using a sterile rayon tipped collection swab (BBL) except for site D (Gap between bowl and floor) where $1 \mathrm{~cm} \times 15 \mathrm{~cm}$ area is swabbed. All households were asked to clean their toilet using their own cleaning products and procedure before the sampling. When households were using a floor mat, swab samples were taken from the floor after removing the floor mat. After the collection, $4 \mathrm{ml}$ of sterile sodium chloride solution was added into each tube, the tube was mixed vigorously, serially diluted using sterile sodium chloride solution (0.85\%), plated with Tryptic Soy Agar (Difco) in duplicate, incubated at $35^{\circ} \mathrm{C}$ for 3 days and appeared colonies are counted. After the first sampling, all households were instructed to use their toilet as usual but not to clean their toilets, and the second swab samples were taken 7 days after the first sampling.

Second study: We selected 12 households in Hyogo prefecture that have at least one boy who can urinate by himself using their toilet (except for two households, average number of family members is 4.00). Eight of them are living in apartments and four of them are living in landed house. Age of the houses are between one year to 26 year (average: 10.25 years old). In December 2018, swab samples were taken from $5 \mathrm{~cm} x$ $15 \mathrm{~cm}$ areas listed in Table 1 using a sterile flock tipped swab (Puritan Medical Products) soaked in sterile sodium chloride solution (0.85\%). All households were asked not to clean their toilet for 1 week before the sampling. When households are using a floor mat, swab samples are taken from the floor after removing the floor mat. Each swab is placed in a tube which contains $4 \mathrm{ml}$ of sterile sodium chloride solution (0.85\%), and analysed as same as the first study.

\section{Residual bacteria growth prevention test}

Test surfaces used in the residual bacteria growth prevention test are, plain cotton (Kanakin \#3, 100\% cotton), terry towel (IKEA, VAGSJON, 100\% cotton), floor mat (IKEA, ALSTERN, 100\% cotton), and vinyl cushion (MEIWA Gravure, Poly Vinyl Chloride). These test surfaces are cut into $2 \mathrm{~cm} \times 2 \mathrm{~cm}$, sterilized by autoclaving at $121^{\circ} \mathrm{C}$ for 15 minutes. The sterilized surfaces are placed in petri dish and exposed to test product placed in an air tight chamber $(100 \mathrm{~cm} \times$ $63.5 \mathrm{~cm} \times 54.5 \mathrm{~cm}$ ) at $23^{\circ} \mathrm{C}$ for 24 hours and 72 hours. After the exposure, the treated surfaces $(0.4 \mathrm{~g})$ are transferred into a $28 \mathrm{~mL}$ sterile glass vial (Maruemu Corporation). Bacteria growth prevention efficacy of the treated surfaces is evaluated using JIS (Japanese Industrial Standard) L1902:2015 (Japanese Standards Association, 2015) absorption method. In addition to Staphylococcus aureus (NBRC12732), Klebsiella pneumoniae (NBRC13277), and Escherichia coli (NBRC3972) listed in JIS L1902, two additional bacteria, Proteus mirabilis (ATCC7002) and Enterococcus hirae (ATCC10541), which were reported to be found from toilet environment (Jeon et al., 2013, Kanayama Katsuse et al., 2017), were tested. The test bacteria is subcultured using nutrient broth, diluted to $1 \times 10^{5} \mathrm{cfu} /$ $\mathrm{ml}$ using $1 / 20^{\text {th }}$ nutrient broth, and $0.2 \mathrm{ml}$ of the bacterial suspension is inoculated into each specimen, incubated at $37^{\circ} \mathrm{C}$ for 24 hours, and bacteria on the surface is extracted by mixing with $20 \mathrm{ml}$ of modified Letheen broth (Difco). Antibacterial activity value is calculated using the below formula. In the case of $\log \mathrm{C}_{0}>\log \mathrm{T}_{0}$, substitute $\log C_{0}$ for $\log T_{0}$.

$A=\left(\log C_{t}-\log C_{0}\right)-\left(\log T_{t}-\log T_{0}\right)$

Where, $A$ : antibacterial activity value, $\log C_{0}$ : common 
TABLE 1. Sampling sites in microbiological investigation of Japanese residential toilets

\begin{tabular}{lll}
\multicolumn{1}{c}{ Study } & \multicolumn{1}{c}{ Location } & \multicolumn{1}{c}{ Sites } \\
\hline First study & Floor, wall and toilet bowl & Floor (10cm distance from bowl) \\
& & Wall (Side of bowl) \\
& Bowl rim surface \\
& Gap between bowl and floor \\
\hline Second study & Floor & Side 10cm distance from bowl \\
& & Side 20cm distance from bowl \\
& Front 10cm distance from bowl \\
& Front 20cm distance from bowl \\
& Under cistern \\
\cline { 2 - 3 } Wall & Side wall $5 \mathrm{~cm}$ distance from floor \\
& Side wall height of bowl \\
& Wall behind cistern \\
\cline { 2 - 3 } & Toilet bowl & Under bowl rim side \\
& Under bowl rim front \\
\hline
\end{tabular}

logarithm of arithmetic average of the numbers of bacteria obtained from three control specimens immediately after inoculation, $\log C_{t}$ : common logarithm of arithmetic average of the numbers of bacteria obtained from three control specimens after 24 hours incubation, $\log T_{0}$ : common logarithm of arithmetic average of the numbers of bacteria obtained from three test specimens immediately after inoculation, and $\log \mathrm{T}_{\mathrm{t}}$ : common logarithm of arithmetic average of the numbers of bacteria obtained from three test specimens after 24 hours incubation. To test efficacy on vinyl cushion, a test surface is covered with a sterile plastic film after inoculation to allow inoculum to contact with the test surface which is recommended by JIS Z2801:2010 (Japanese Standards Association, 2010).

\section{Air freshener product which provide bacteria growth prevention efficacy on permeable surfaces}

The air freshener product we previously developed (Vyas et al., 2018) consists of apparatus including volatile carbonyl compounds that deposit on permeable surfaces in toilet environment and neutralize malodorous compounds absorbed in the surfaces. We newly identified additional combination of volatile compounds from below 2 groups that have effective bacteria growth prevention efficacy; (i) C5 to C8 unbranched unsubstituted linear alkenal and (ii) C9 to C14 unbranched unsubstituted linear alkenal. Specifically, having two different types of alkenals instead of one single alkenal increases longevity of a bacteria growth prevention benefit because the C5 to C8 unbranched unsubstituted linear alkenal and the C9 to C14 unbranched unsubstituted linear alkenal have different vaporization rates and can act in tandem to enhance an overall bacterial growth prevention efficacy in a sequential manner. Exemplary alkenals are listed in the Table 2 and Table 3. Table 4 shows a mixture of $\mathrm{C} 5$ to $\mathrm{C} 8$ and $\mathrm{C} 9$ to $\mathrm{C} 14$ unbranched unsubstituted linear alkenals suitable for use in the composition used for this study.

\section{Volatile compounds adsorption into permeable surfaces}

Cotton (Kanakin \#3) was analysed to measure the amount of air freshener volatile materials adsorbed. These test surfaces were cut into $2 \mathrm{~cm} \times 2 \mathrm{~cm}$, sterilized by autoclaving at $121^{\circ} \mathrm{C}$ for 15 minutes. The sterilized surfaces were placed in petri dish and exposed to test product placed in an air tight chamber $(100 \mathrm{~cm} \times$ $63.5 \mathrm{~cm} \times 54.5 \mathrm{~cm}$ ) at $23^{\circ} \mathrm{C}$ for 15,24 and 72 hours. Six pieces of cotton were placed in a $22 \mathrm{~mL}$ glass vial and extracted overnight with $5 \mathrm{~mL}$ of methanol. In a separate vial, $4.5 \mathrm{~mL}$ of $20 \%$ sodium chloride solution and $0.5 \mathrm{~mL}$ of the methanol extract were added, and headspace was analysed by solid phase micro-extraction - gas chromatograph mass spectrometry (SPME-GCMS; 100 um Polydimethylsiloxane fiber, Agilent GC 7890B Mass detector 5977A coupled with a Gerstel MPS2 autosampler; column HP-5MS ultra inert 30m x 250 $\mu \mathrm{m}$ $\times 0.25 \mu \mathrm{m})$. SPME parameters: $10 \mathrm{~min}$ incubation at $65^{\circ} \mathrm{C}, 5$ min extraction and 5 min desorption time at $250^{\circ} \mathrm{C}$ ). Quantification is done with a calibration curve of spikes prepared in the same way.

\section{Statistical analysis}

Variables are analyzed using mixed-effects regression model. The model includes a random subject effect and fixed effects for site. A normal plot of the residuals is examined to assess the assumptions of the models. The standardized residuals are assessed for outliers (points that lie far beyond the scatter of the remaining residuals, i.e. four or more standard deviations from zero). A cut-off of 0.05 (2-sided) is used for all comparisons as significance level. 
TABLE 2. C5 to C8 unbranched unsubstituted linear alkenals

\begin{tabular}{l|l}
\hline \multicolumn{1}{c|}{ CAS } & \multicolumn{1}{c}{ IUPAC Name } \\
\hline $764-39-6$ & 2-Penten-1-al \\
\hline $5604-55-7$ & 3-Penten-1-al \\
\hline $2100-17-6$ & 4-Penten-1-al \\
\hline $6728-26-3$ & (E)-2-Hexen-1-al \\
\hline $16635-54-4$ & (Z)-2-Hexen-1-al \\
\hline $69112-21-6$ & 3-Hexen-1-al \\
\hline $25166-87-4$ & 4-Hexen-1-al \\
\hline $18829-55-5$ & 2-Hepten-1-al \\
\hline $89896-73-1$ & 3-Hepten-1-al \\
\hline $929-22-6$ & 4-Hepten-1-al \\
\hline $2363-89-5$ & 2-Octen-1-al \\
\hline $76595-71-6$ & 3-Octen-1-al \\
\hline $78693-35-3$ & 4-Octen-1-al \\
\hline
\end{tabular}

TABLE 3. C9 to C14 unbranched unsubstituted linear alkenals

\begin{tabular}{l|l}
\hline \multicolumn{1}{c|}{ CAS } & \multicolumn{1}{c}{ IUPAC Name } \\
\hline 18829-56-6 & 2-Nonen-1-al \\
\hline $31823-43-5$ & 3-Nonen-1-al \\
\hline $2277-16-9$ & 5-Nonen-1-al \\
\hline $3913-81-3$ & 2-Decen-1-al \\
\hline $65405-70-1$ & 4-Decen-1-al \\
\hline $60671-72-9$ & 5-Decen-1-al \\
\hline $2463-77-6$ & 2-Undecen-1-al \\
\hline $68820-32-6$ & 4-Undecen-1-al \\
\hline $4826-62-4$ & 2-Dodecen-1-al \\
\hline $68141-15-1$ & 3-Dodecen-1-al \\
\hline $21944-98-9$ & 4-Dodecen-1-al \\
\hline $68820-33-7$ & 5-Dodecen-1-al \\
\hline $7774-82-5$ & 2-Tridencen-1-al \\
\hline $98474-68-1$ & 4-Tridecen-1-al \\
\hline $64461-99-00$ & 2-Tetradecen-1-al \\
\hline
\end{tabular}

TABLE 4. A mixture of $\mathrm{C} 5$ to $\mathrm{C} 8$ and $\mathrm{C} 9$ to $\mathrm{C} 14$ unbranched unsubstituted linear alkenals suitable for use in the composition used for this study

\begin{tabular}{c|c|c|c}
\hline CAS No. & IUPAC Name & Weight \% by weight of the Composition & Average Vapor Pressure (Torr) at 25 degrees Celsius \\
\hline $6728-26-3$ & (E)-2-Hexen-1-al & $0.25 \%$ to $10 \%$ & 10.7 \\
\hline $3913-81-3$ & (E)-2-Decen-1-al & $0.25 \%$ to $10 \%$ & 0.0674 \\
\hline
\end{tabular}

\section{RESULTS}

\section{Microbiological investigation of Japanese residential toilets}

First study: The first study results of bacterial quantification of toilet environment are shown in Figure 1. After the first cleaning, site $D$ (the gap between toilet bowl and floor) has the highest number of bacteria followed by site $\mathrm{C}$ (toilet bowl rim surface), site A (floor) and site $B$ (wall). After the 7 days usage without cleaning, site $D$ (the gap between toilet bowl and floor) has the highest number of bacteria followed by site A (floor), site C (toilet bowl rim surface) and site B (wall). The number of bacteria on site A (floor) increased significantly after 7 days usage but the number of bacteria has no significant change on other sites.

Second study: The second study results of bacterial quantification of toilet environment are shown in Figure 2. Site $M$ and site $N$ (backside of toilet bowl rim) have significantly higher number of bacteria among the tested sites followed by floor and wall. On the floor, the distance from toilet bowl and the place of the floor do not give significant difference to bacterial number found when we compare between site $\mathrm{G}$ (10cm distance from bowl front) and site $\mathrm{H}$ (20 cm distance from bowl front), and between site $E$ ( $10 \mathrm{~cm}$ distance from bowl side) and site $\mathrm{F}$ (20cm distance from bowl side).

\section{Residual bacteria growth prevention test}

The residual bacteria growth prevention efficacy test results on the tested surfaces are shown in Table 5. The robust bacteria growth prevention activity value is seen on the 72 hours treated surfaces against selected Gram positive bacteria as well as Gram negative bacteria. These bacteria are found from human gut too as described in another study (Nishijima et al., 2016). According to JIS L1902:2015, when the antibacterial activity value is more than 2 but less than 3 , the antibacterial efficacy is considered as "Effect". When the antibacterial activity value is more than 3 , the antibacterial efficacy is considered as "Full effect". Except for the efficacy on vinyl cushion against Klebsiella pneumoniae (2.9), other results are more than 3. More than 2.0 antibacterial activity value is found on 24 hours treated surfaces too on floor mat and vinyl cushion against S.aureus, E.coli and E.hirae. 


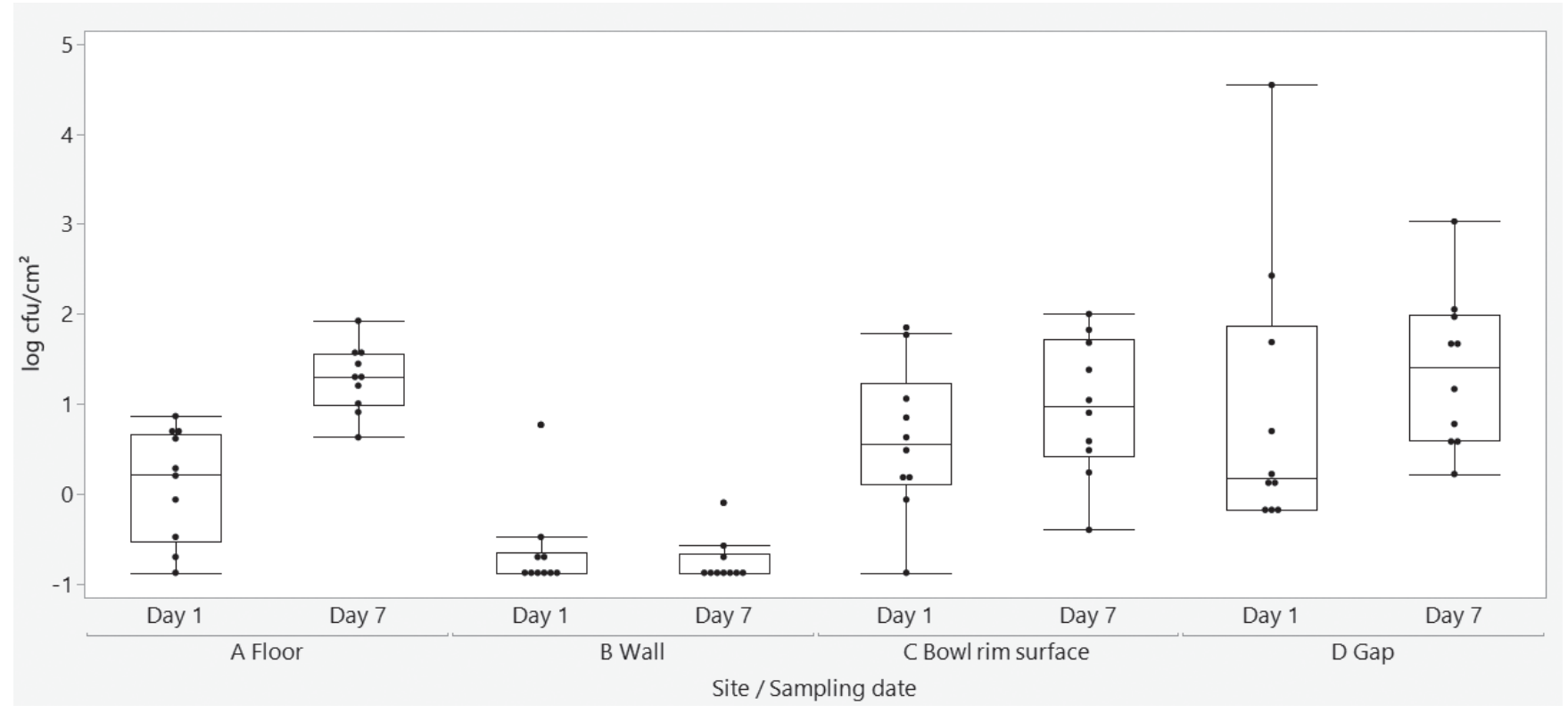

FIGURE. 1. Bacterial number in toilet surfaces (Log cfu/ $\left.\mathrm{cm}^{2}\right)$ - First study

$5 \mathrm{~cm} \times 15 \mathrm{~cm}$ area of each site (Table 1; site $A$ to site $D$ ) is swabbed by using a moistened cotton swab (except for site $D$ where $1 \mathrm{~cm} \times 15 \mathrm{~cm}$ area is swabbed) and bacterial number on each area is enumerated by agar dilution method. Each data is expressed as $\log \mathrm{cfu} / \mathrm{cm}^{2}$, the data is collected from 10 households. Day 1 samples are taken on the first day after cleaning and Day 7 samples are taken on the $7^{\text {th }}$ day (after 7 days usage without cleaning).

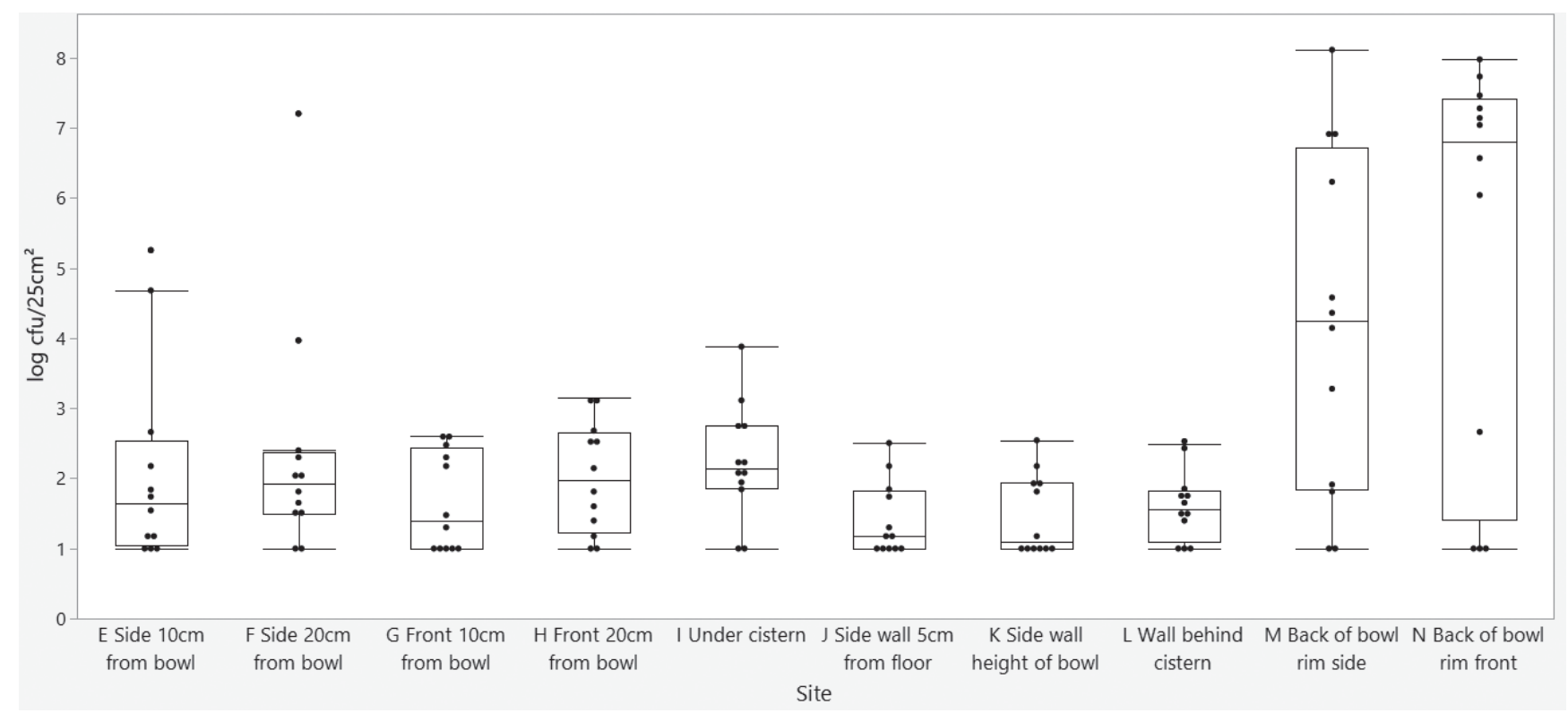

FIGURE. 2. Bacterial number in toilet surfaces $\left(\right.$ Log cfu/ $\left.\mathrm{cm}^{2}\right)$ - Second study

$5 \mathrm{~cm} \times 15 \mathrm{~cm}$ area of each site (Refer to Table 1; site $\mathrm{E}$ to site $\mathrm{N}$ ) is swabbed by using a moistened cotton swab and bacterial number on each area is enumerated by agar dilution method. Each data is expressed as log cfu/ $\mathrm{cm}^{2}$, the data is collected from 12 households. 
TABLE 5. Antibacterial activity value against 5 tested bacteria on Kanakin, Terry towel, Floor mat and Vinyl cushion According to JIS L1902:2015, when antibacterial activity value is more than 2.0, the antibacterial efficacy is "effect". When antibacterial activity value is more than 3.0, the antibacterial efficacy is "full effect". A: antibacterial activity value, $\log \mathrm{C}_{0}$ : common logarithm of arithmetic average of the numbers of bacteria obtained from three control specimens immediately after inoculation, log $\mathrm{C}_{\mathrm{t}}$ : common logarithm of arithmetic average of the numbers of bacteria obtained from three control specimens after 24 hours incubation, $\log T_{0}$ : common logarithm of arithmetic average of the numbers of bacteria obtained from three test specimens immediately after inoculation, and $\log \mathrm{T}_{\mathrm{t}}$ : common logarithm of arithmetic average of the numbers of bacteria obtained from three test specimens after 24 hours incubation. When the number of colonies is less than 1 in the petri dishes with $1 \mathrm{ml}$ of shake-out bacteria suspension, $\log T_{t}$ is expressed as "<1.00".

\begin{tabular}{|c|c|c|c|c|c|c|c|}
\hline & & & $\log C_{0}$ & $\log C_{t}$ & $\log T_{0}$ & $\log T_{t}$ & $A$ \\
\hline \multirow[t]{5}{*}{ Kanakin } & 72 hours & S.aureus & 4.55 & 7.21 & 4.42 & 2.83 & 4.38 \\
\hline & & E.coli & 4.43 & 8.07 & 4.43 & $<1.00$ & $>7.07$ \\
\hline & & K.pneumoniae & 4.49 & 7.63 & 4.42 & $<1.00$ & $>6.63$ \\
\hline & & P.mirabilis & 4.47 & 7.32 & 4.37 & $<1.00$ & $>6.32$ \\
\hline & & E.hirae & 4.40 & 7.28 & 4.35 & 4.24 & 3.04 \\
\hline \multirow[t]{5}{*}{ Terry towel } & 72 hours & S.aureus & 4.56 & 7.16 & 4.58 & 2.65 & 4.52 \\
\hline & & E.coli & 4.40 & 8.20 & 4.31 & $<1.00$ & $>7.20$ \\
\hline & & K.pneumoniae & 4.49 & 7.48 & 4.47 & $<1.00$ & $>6.48$ \\
\hline & & P.mirabilis & 4.48 & 7.53 & 4.46 & $<1.00$ & $>6.53$ \\
\hline & & E.hirae & 4.44 & 7.33 & 4.46 & $<1.00$ & $>6.35$ \\
\hline \multirow[t]{8}{*}{ Floor mat } & 24 hours & S.aureus & 4.47 & 6.65 & 4.33 & $<1.00$ & $>5.65$ \\
\hline & & E.coli & 4.48 & 8.26 & 4.4 & 5.74 & 2.52 \\
\hline & & E.hirae & 4.54 & 7.45 & 4.55 & 3.55 & 3.92 \\
\hline & 72 hours & S.aureus & 4.45 & 7.20 & 4.33 & 1.91 & 5.29 \\
\hline & & E.coli & 4.48 & 8.15 & 4.41 & 3.70 & 4.45 \\
\hline & & K.pneumoniae & 4.49 & 7.80 & 4.48 & $<1.00$ & $>6.80$ \\
\hline & & P.mirabilis & 4.49 & 6.62 & 4.36 & $<1.00$ & $>5.62$ \\
\hline & & E.hirae & 4.54 & 7.96 & 4.49 & 4.21 & 3.75 \\
\hline \multirow[t]{8}{*}{ Vinyl cushion } & 24 hours & S.aureus & 4.49 & 5.70 & 4.31 & 3.28 & 2.42 \\
\hline & & E.coli & 4.50 & 7.61 & 4.42 & 3.92 & 3.69 \\
\hline & & E.hirae & 4.59 & 6.73 & 4.5 & 2.30 & 4.44 \\
\hline & 72 hours & S.aureus & 4.49 & 6.06 & 4.33 & 2.08 & 3.98 \\
\hline & & E.coli & 4.50 & 7.58 & 4.52 & 3.86 & 3.74 \\
\hline & & K.pneumoniae & 4.57 & 7.08 & 4.5 & 4.17 & 2.91 \\
\hline & & P.mirabilis & 4.52 & 6.27 & 4.45 & $<1.00$ & $>5.27$ \\
\hline & & E.hirae & 4.59 & 7.00 & 4.51 & 1.20 & 5.80 \\
\hline
\end{tabular}

\section{Volatile compounds adsorption into permeable surfaces}

The results of adsorption of the volatile evaporated from the product over time in cotton are shown in Figure 3. Cotton absorbed $2.7 \mu \mathrm{g} / \mathrm{cm}^{2}$ of volatiles at 72 hours which seems to be reaching to the maximum adsorption capacity.

\section{DISCUSSION}

In this study, we found unique habitats of microorganisms in residential toilet room surfaces. Microbiological studies of residential toilets have been done mainly for inside of toilet bowl because toilet bowl has been considered as a source of spreading bacterial or viral infectious diseases, and because there are aesthetic 


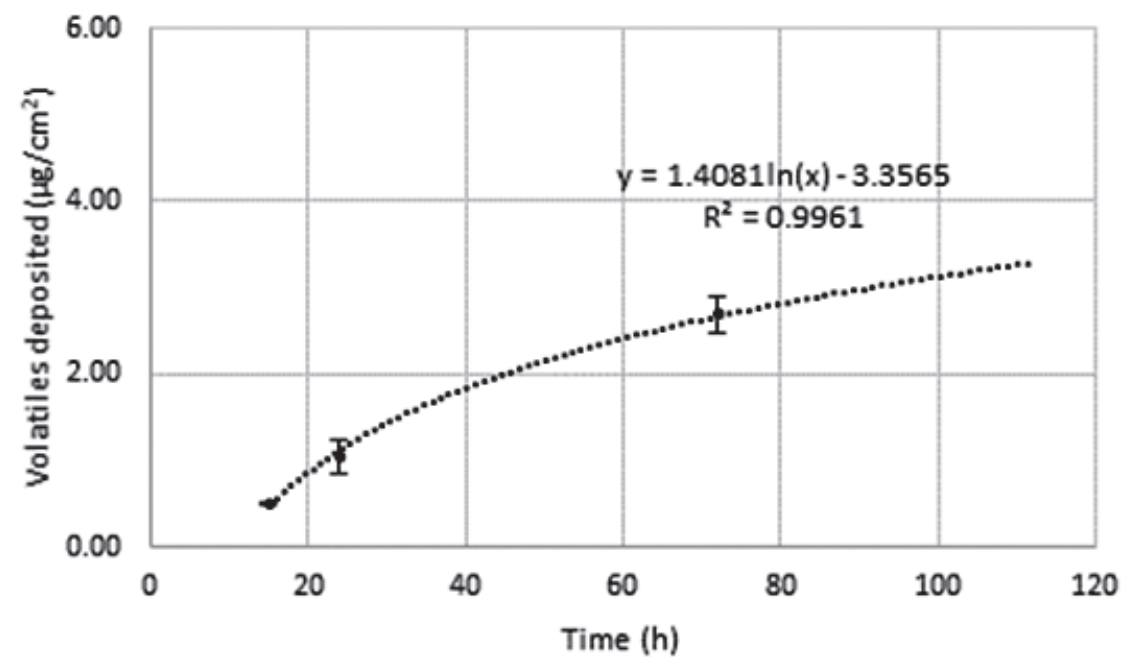

FIGURE. 3. Volatile compounds adsorption into permeable surfaces

concerns such as malodor caused by microorganisms (Fukano et al., 2015, Mori et al., 2013, Pitts et al., 1998). Because there is higher malodor concerns and bigger hygienic importance, there are more studies on public toilets that look at outside surfaces of toilet bowl (Flores et al., 2011, Fouquier et al., 2016, Gibbons et al., 2015).

We found under the toilet bowl rim has the highest bacterial population among the sites we have tested. Under the rim is well recognized site where cleaning utensils such as toilet brushes are usually hard to reach which resulted in accumulation of human wastes and microorganisms and production of malodor and scale. Ohki et al. (2010) analysed scale formed under the rim and found that it consisted of calcium phosphates, struvite, calcium carbonate, uric acid and proteins. Scale surfaces are usually rough and porous. As such, it will promote soil attachment and bacterial growth, and lead to malodour formation. Egert et al. (2010) analysed microbial composition of biofilms from under the rim of domestic toilets and found the typical organisms belong to a-Proteobacteria and Actinobacteria such as Brevundimonas.

Gap between toilet bowl bottom and floor is not particularly mentioned in existing publications but many consumers are concerned about this area because urine spill may reach there, which is hard to clean as well as under the rim. Bacterial population of the gap was found to be as high as toilet bowl rim surface and accumulation of dirt are visible in some of the toilets we visited. To eliminate the "gap", physically sealing with silicone sealant or products designed to fill the gap can be used.
Toilet room floors are moderately contaminated by bacteria, the number of bacteria found on toilet floor is similar to a previous study by Ojima et al. (2002). Suzuki et al. (Proceedings of the $57^{\text {th }}$ annual meeting of the society of home economics, 2015) found that significant amount of urine splashes is observed on floor in front of toilet bowl as well as backside of the bowl rim. These urine splashes on floor would promote bacterial growth there and produce malodor. Lion corporation published study results (2015) that dusts on toilet floor contain up to millions of bacteria in 1 gram of dust which is higher than dust in other rooms, and these dusts enhance the growth of Staphylococcus aureus and Escherichia coli. This may explain why we found the number of bacterial populations on floor significantly increased after 7 days usage and higher number of bacteria is found under cistern than other toilet floor areas.

Built environmental sanitization technique using gaseous actives has been discussed for the purpose of hazardous biological agent removal after bioterrorism attack (Rastogi et al., 2010), and in animal research facilities (Shirasaki et al,. 2016). However, for residences, such highly efficacious technology which works in short period of time is not appropriate because people are continuously staying in the environment so that human inhalation safety of such active is one of the biggest elements to be assured. Essential oils are materials that meet such requirements and many essential oils are known to possess antibacterial efficacy (ReyesJurado et al., 2019). The 2 volatiles we have added in our toilet deodorizer are known to be contained in an essential oil and often used perfume raw materials. 
Since there is no standard procedure to evaluate bacteria growth prevention efficacy of essential oils in the vapor phase, several techniques are recommended including zone of inhibition observation using inverted petri dish (Kloucek et al., 2012), Minimum Inhibitory Concentration (MIC) determination of the vapor phase using a chamber (Suhr and Nielsen., 2003) or using a vial specially designed to measure efficacy of essential oils in the vapor phase (Seo et al., 2015, Lee at al., 2018), and the agar plug vapor phase assay by which enabled quantitative evaluation (Amat et al., 2017) as summarized by Reyes-Jurado et al. (2019).

Required amount of essential oils to deliver antimicrobial benefit in certain closed environment can be calculated based on MIC or Minimum Lethal Concentration (MLC) data generated by these test methods. For example, essential oil of Clove has robust antimicrobial efficacy which the MIC is $9.0 \mu \mathrm{g} / \mathrm{L}$ on Yersinia enterocolitica (Goñi et al., 2009) but residential toilet size is approximately 1900 2000L. Therefore, if we want to deliver bacteria growth prevention benefit using essential oils to such residential toilet space, we need to evaporate very high amount of essential oils.

We designed an air freshener product which the antibacterial active evaporates, deposit on permeable surfaces in toilet room, and deliver the bacterial growth prevention efficacy on the permeable surfaces. This mechanism of bacteria growth prevention efficacy enables delivery of malodor prevention from the secondary malodor sources with a practical concentration of the antibacterial actives in the air freshener product. The residual bacteria growth prevention test method we used here to evaluate the air freshener product simulates well this active delivery mechanism in real residential toilet room condition.

Volatile compounds adsorption into permeable surfaces was conducted to understand dynamic equilibrium of volatile adsorption over time. The results of adsorption of the volatile evaporated from the product over time in cotton are shown in Figure 3. Cotton absorbed $2.7 \mathrm{\mu g} / \mathrm{cm}^{2}$ of volatiles at 72 hours which seems to be reaching the equilibrium condition. Residual bacteria growth prevention test was conducted on surfaces that were exposed to product for 24 hours and 72 hours period and the results are shown in Table 5. Both the tests delivered the residual bacteria growth prevention efficacy. So even before reaching the equilibrium condition of volatile adsorption on surfaces, residual bacteria growth prevention efficacy was being delivered. Given nature of the product that it continuously delivers volatiles in the air thus enables the surfaces to adsorb the volatiles continuously, reach and remain at surface adsorption equilibrium stage.

\section{REFERENCES}

Amat, S., Baines, D., and Alexander, T. W., (2017) A vapour phase assay for evaluating the antimicrobial activities of essential oils against bovine respiratory bacterial pathogens, Letters in Applied Microbiology, 65, 489-495

Egert, M., Schmidt, I., Bussey, K., and Breves, R., (2010) A glimpse under the rim - the composition of microbial biofilm communities in domestic toilets. Journal of Applied Microbiology, 108, 1167-1174.

Flores, G. E., Bates, S. T., Knights, D., Lauber, C. L., Stombaugh, J., Knight, R., and Fierer, N., (2011) Microbial biogeography of public restroom surfaces, PLoS one, 6, e28132

Fouquier, J., Schwarts, T., and Kellet, S. T., (2016) Rapid assemblage of diverse environmental fungal communities on public restroom floors, Indoor Air, 26, 869-879

Fukano, T., Gomi, M., Osaki, Y., and Morikawa, M., (2015) Isolation and characterization of an early colonizing Rhizobium sp. R8 from a household toilet bowl. Bioscience, Biotechnology, and Biochemistry, 79, 1207-1215

Gibbons, S. M., Schwartz, T., Fouquier, J., Mitchell, M., Sangwan, N., Gilbert, J. A., and Kelley, S. T., (2015) Ecological succession and viability of human-associated microbiota on restroom surfaces, Applied and Environmental Microbiology, 81, 765-773

Goñi, P., P. López, C. Sánchez, R. Gómez-Lus, R. Becerril, and C. Nerín. (2009) Antimicrobial activity in the vapour phase of a combination of cinnamon and clove essential oils. Food Chemistry, 116, 982-989

lyo, T., Asakura, K., Nakano, M., Yamada, M., and Omae, K., (2016) Bidet toilet seats with warm-water tanks: Residual chlorine, microbial community, and structural analyses. Journal of Water and Health, 14, 68-80

Japanese Standards Association, Japanese Industrial Standard JIS L1902:2015 Textiles - Determination of antibacterial activity and efficacy of textile products

Japanese Standards Association, Japanese Industrial Standard JIS L2801:2010 Antibacterial products - Test for antibacterial activity and efficacy

Jeon, Y., Chun, J., and Kim, B. (2013) Identification of household bacterial community and analysis of species shared with human microbiome, Current Microbiology, 67, 557-563

Kanayama Katsuse, A., Takahashi, H., Yoshizawa, S., Tateda, K., Nakahishi, Y., Kaneko, A., and Kobayashi, I., (2017) Public health and healthcare-associated risk of electric, warm-water bidet toilets. Journal of Hospital Infection, 97, 296-300.

Kloucek, P., Smid, J., Frankova, A., Kokoska, L., Valterova, I., and Pavela, R., (2012) Fast screening method for assessment of antimicrobial activity of essential oils in vapor phase, Food Research International, 47, 161-165

Lee, G., Kim, Y., Kim, H., Beuchat, L. R., and Ryu, J., (2018) Antimicrobial activities of gaseous essential oils against Listeria monocytogenes on a laboratory medium and radish sprouts, International Journal of food microbiology, 265, 49-54

Mori, M., Gomi, M., Matsumune, N., Niizeki, K., and Sakagami, Y., (2013) Biofilm-Forming Activity of Bacteria Isolated from Toilet Bowl Biofilms and the Bactericidal Activity of Disinfectants against The Isolates. Biocontrol 
Science, 18, 129-135

Mori, M., Nagata, Y., Niizeki, K., Gomi, M., and Sakagami, Y., (2014) Characterization of microorganisms isolated from the black dirt of toilet bowls and componential analysis of the black dirt. Biocontrol Science, 19, 173-179

Nishijima, S., Suda, W., Oshima, K., Kim, S., Hirose, Y., Morita, H., and Hattori, M., (2016) The gut microbiome of healthy Japanese and its microbial and functional uniqueness, DNA research, 23, 125-133

Ohki, T., Nishikawa, N., Hasegawa, T., Okano, T., and Tanizawa, Y., (2010) Characterization of scale formed on the surfaces of toilet bowls, Journal of Surfactants and Detergents, 13, 19-26

Ojima, M., Toshima, Y., Koya, E., Ara, K., Tokuda, H., Kawai, S., Kasuga, F., and Ueda, N., (2002) Hygiene measures considering actual distributions of microorganisms in Japanese households. Journal of Applied Microbiology, 93, 800-809

Pitts, B., Stewart, P. S., McFeters, G. A., Hamilton, M. A., Willse, A., and Zelver, N., (1998) Bacterial characterization of toilet bowl biofilm. Biofouling, 13, 19-30

Rastogi, V. K., Ryan, S. P., Wallace, L., Smith, L. S., Snah, S. S., and Martin, G. B., (2010) Systematic evaluation of the efficacy of chlorine dioxide in decontamination of building interior surfaces contaminated with anthrax spores, Applied and Environmental Microbiology, 76, 3343-3351

Reyes-Jurado, F., Navarro-Cruz, A. R., Ochoa-Velasco, C. E., Palou, E., Lopez-Malo, A., and Avila-Sosa, R., (2019) Essential oils in vapor phase as alternative antimicrobials: $A$ review, Critical Reviews in Food Science and Nutrition, 18, 1-10

Seo, H., Beuchat, L. R., Kim, H., and Ryu, J., (2015) Development of an experimental apparatus and protocol for determining antimicrobial activities of gaseous plant essential oils, International Journal of Food Microbiology, 215, 95-100

Shirasaki, Y., Matsuura, A., Uekusa, M., Ito, Y., and Hayashi, T., (2016) A study of the properties of chlorine dioxide gas as a fumigant, Experimental Animals, 65, 303-310

Suhr, K. I., and Nielsen, P. V., (2003) Antifungal activity of essential oils evaluated by two different application techniques against rye bread spoilage fungi, Journal of Applied Microbiology, 94, 665-674

Vyas, R., Chauhan, G., Madhuri, K., and Saini, G., (2018) Apparatus and method for reducing malodor on surfaces, Patent WO2019/089739 